\title{
USING SOLAR ENERGY ON SPROUTING OF POTATO TUBERS SEED THROUGH STORAGE PERIOD BEFORE PLANTING
}

\author{
Taha, A. T ${ }^{(1)}$; Aboamera, M. A.(2) ; Abboud, A. GH. ${ }^{(3)}$ \\ ABSTRACT
}

Recently serious attention has been given to the possibility of increasing agriculture production of potato seed with good quality. The importance of knowing the suitable weather condition from temperature ranged between 18-25 ${ }^{\circ} \mathrm{C}$ and its effect on breaking dormancy period of potato seed to get on more sprouts per tuber seed. In Egypt during January potato seeds are imported and during this month the temperature is lower and ranged between $\left(10-13{ }^{\circ} \mathrm{C}\right)$. The main objectives of this work was to study the feasibility of adapting the weather condition around potato seed before planting by solar energy. The obtained results supported using greenhouse due to increasing the ratio of sprouting, earlier emergence, more stems and numbers of new tubers per square meter and more yield in case of storage the seed potato tubers inside the greenhouse for 8 days compared with seed potato tubers that stored in open air outside greenhouse by more than $12 \%$.

\section{INTRODUCTION}

7 he potato (Solanum tuberosum L.) tubers follow only rice and wheat in world importance as a food crop for human . Imported L seeds are received in Egypt during December where low weather temperature occurred. It will need long time to break dormancy, Imported seeds are received in Egypt during December where low weather temperature occurred. It will need long time to break dormancy, give more sprouts before planting which delay planting and harvesting causing problems with tuber moth and bacterial diseases resulting significant loss in yield.

(1) Associate professor of Agric. Eng. Dept., Fac. of Agric., Menoufia Univ.

(2) Professor of Agric. Eng. Dept., Fac. of Agric., Menoufia Univ.

(3) Agric. manager, International agric. Company. (Farmfrites-Egypt) 
Accelerating sprouting in potato seeds can be done by several methods to break dormancy. When dormancy is over, the storage temperature determines the initiation of visible sprout growth. The pattern of sprout growth of potato tuber depend on the physiological stage of the tuber (i.e. growing condition, storage condition, length of storage period, and previous sprout growth), temperature at which sprouting occurs, light conditions, relative humidity and competition between sprouts (tuber size and number of sprouts) (Beukema and Zaag, 1990).Heating affect tubers sprout by keeping it in a dark room at $18-25{ }^{\circ} \mathrm{C}$ until sprouting occurs. Cold shock plus heat resulted in early maturing varieties or when the dormant period is almost finished. The tubers are harvested, cleaned and allowed to supersize (cuts and bruises healed). They are placed in $4{ }^{\circ} \mathrm{C}$ for two or more weeks, and then held at $18-25{ }^{\circ} \mathrm{C}$. If sprouts do not appear within two to three weeks, either repeat the process or treat the tubers with gibberellic acid (Bryan, 1989). The temperature influence on sprout growth, where with an increase in temperature from $4{ }^{\circ} \mathrm{C}$ to $25^{\circ} \mathrm{C}$ there is an increase in the initial rate of elongation of the apical sprout of tubers of the Arran pilot variety .The growth rate at $30{ }^{\circ} \mathrm{C}$ is low. This also occurs later in the $25^{\circ} \mathrm{C}$ and $20{ }^{\circ} \mathrm{C}$ treatments, so that eventually the longest sprouts are produced at $15{ }^{\circ} \mathrm{C}$ (Beukema and Zaag, 1990). Greenhouse air humidity increased considerably close to the lower leaf surface, particularly during daytime when crop transpiration is maximum .The consequences of greenhouse ventilation on the decoupling between outside and inside climate and between the latter and the climate in the neighborhood of the leaves .The ventilation dependence of inside air climate and of the climate in the leaf boundary-layer in two greenhouse tomato crop tunnels differing only in their ventilation conditions. The wind speed and vent opening govern greenhouse ventilation flux and the resulting inside air speed, which determines inside air humidity, more particularly in the leaf boundary-layer and at leaf level. Inside air speed is also much higher in the area situated near the vent openings than in the centre of the tunnel and consequently inside climate and leaf boundarylayer climates near the vents or the open gable ends are more tightly coupled to outside conditions (Boulard et al., 2005). If high yields per plant are desired, plant density should be low, whereas it should be high 
when high yields per hectare are required. Two kinds of competition may occur in potato field: competition between plants and competition within the plant (i.e. competition between stems).Competition within the plant becomes increasingly important the wider the distance between the plants and the larger the number of stems per plant (Beukema and Van der Zaag, 1990). Greenhouse depends upon three parameters:

1. The surface area of the greenhouse;

2. The location of the greenhouse and crop to be grown; and

3. The greenhouse heat loss rate which is largely dependent upon the glazing material.

Two of these are readily determined, and the third is an approximation depending upon the glazing and its condition and whether or not thermal screens are in place (Roberts, 1997).Tuber dormancy is a physiological state characterised by a period during which autonomous sprout growth does not occur, even under optimal sprouting conditions (darkness, 15 to $20{ }^{\circ} \mathrm{C}$, relative humidity about $90 \%$ ). Dormancy is regarded as a period in the tuber life cycle from initiation to the time when sprouting starts. However, since this period is difficult to determine, post-harvest dormancy is used for practical purposes, and is defined as the period from dehaulming to the time when $80 \%$ of tubers show sprouts at least $2 \mathrm{~mm}$ long (Pande et al.,2007). Potato yields are affected by several factors, but the basic factor is seed quality, especially its biological quality. Application of fertilizers and irrigation, as well as appropriate crop management, could be more effective when good quality seed is used. Good returns from potato production are the driving force for using quality seed (Wang et al., 2009). The purpose of the heating system is to replace energy lost from the greenhouse when outside temperatures are lower than desired in the greenhouse growing area. Ideally the heating system should have a variable output capable of matching the changing heat load caused by the outside weather conditions. Heat is transferred by conduction, convection, and radiation. Conduction is the transfer of heat through a solid material (Robert, 1997).Environmental control of greenhouses includes control and modification of day and night temperatures, relative humidity, and carbon dioxide levels for optimum plant growth. Extremes of temperatures and humidity are encountered 
during winter and summer. A well-designed production facility will normally provide an environment with temperature set points between 55 and $85^{\circ} \mathrm{F}$, with humidity levels high enough to reduce water stress and low enough to discourage disease and fungus outbreaks in the crop. When $\mathrm{CO}_{2}$ enrichment is required, $1000 \mu \mathrm{mol} / \mathrm{mol}(\mathrm{ppm})$ is often considered the desired target level (Roberts, 1997). During the passage of the beam radiation downwards through the atmosphere, it is split up into three parts. One part is reflected back into space mainly by clouds, another part is scattered in all direction by molecules of dry air, water vapor, carbon dioxide, and ozone. While the remainder part is transmitted through the atmosphere being received at the ground as beam or direct radiation (Duffie and Beckman, 1980). High relative humidity simulates root formation on the sprouts. The longitudinal growth of the sprouts does not seem to be greatly influenced by the relative humidity at moderate temperature. At higher temperatures high relative humidity may stimulate the longitudinal growth of the sprouts. A liberal amount of water also stimulates the main objective of this study was increasing the tubers sprout during stage of sprouting before planting to increase yield (Beukema and Zaag, 1990). It is believed that the five major plant hormones are involved in the process; Abscisic acid and Ethylene are involved in the induction of dormancy, Cytokinins are involved in dormancy break, and are involved in sprout development. The importance of hydrogen peroxide and antioxydant system was also demonstrated (Delaplace et al., 2008).

\section{MATERIALS AND METHODS}

To achieve this purpose includes conducted the following parameters, effect of using solar radiation on potato tubers sprouting. The study was carried out at the International Company for Agriculture Development (Farm Frites, Egypt) in El-Hashemeia farm -Wady El- Natroon -Elbehira governorate during summer seasons 2013 . The latitude angle was $\mathrm{E}\left(30^{\circ}\right.$ $\left.01^{`} 14^{\prime \prime}\right), \mathrm{N}\left(30^{\circ} 18^{`} 30^{\prime \prime}\right)$.

Plastic covered greenhouse has $9 \mathrm{~m}$ width and $50 \mathrm{~m}$ length was installed in the experimental location. The height of the greenhouse at the center was $3.10 \mathrm{~m}$ and was $2 \mathrm{~m}$ at both sides. The greenhouse was covered with 
single polyethylene (PE) sheet of 200.0 micron thickness. The plastic film has the following characteristics:

Heat capacity $=0.014 \mathrm{Wh} \mathrm{kg}^{-1} \mathrm{~K}^{-1}$; Conductivity $0.064 \mathrm{Wm}^{-1} \mathrm{~K}^{-1}$; Density $920 \mathrm{kgm}^{-3}$; Light transmissions (direct radiation $84 \%$ and light diffuse radiation $80 \%$ ).

\section{Seed potato tubers}

The cultivars of Innovator potato seeds variety certified seeds, class E was imported from HZPC company-Netherland.

\section{Experimental treatments}

In order to achieve the main objective of this study, four factors were studied and changed in different levees; these factors were:

(a) Tuber diameter (two levels $35-45 \mathrm{~mm}$ and $45-50 \mathrm{~mm}$ ) were considered;

(b) Storage place (two storage places inside greenhouse and outside greenhouse) were used;

(c) Packing material three types of packing materials were used; Jumbo with $1.25 \mathrm{Mg}$, wooden box with $1.25 \mathrm{Mg}$ and small net bag with $0.033 \mathrm{Mg}$ which average 38 nets were arranged vertically with $1.25 \mathrm{Mg}$ weight total.

(d) Storage period three different periods were limited; 4, 6 and 8 days.

\section{Experimental procedure}

Storing period of packets in both inside greenhouse and in the open field was taken in three levels which were, 4, 6 and 8 days. During this period, air temperature, relative humidity and solar radiation were recorded every one hour. Before storing, the number of sprouts that located on the tuber surface were counted for each treatment for inside the greenhouse and the open field. Four samples were taken randomly from each treatment, each includes 100 tubers and the average number of sprouts was derived at the end of each storing period.

\section{Air temperature and relative humidity}

In each storage treatment, the value of air temperature and relative humidity taken at the center of each seed tuber packet (at a depth of 60 $\mathrm{cm}$ from the top surface of jumbo) as showed in figure (1), soil temperature (at a depth of $15 \mathrm{~cm}$ ) at storage place center inside and outside the greenhouse. 


\section{Solar radiation measurements:}

Solar intensity was measured using "Dacom weather station and Silicon Pyranometer "which located at the experimental site. The used apparatus was presented in figure (2)

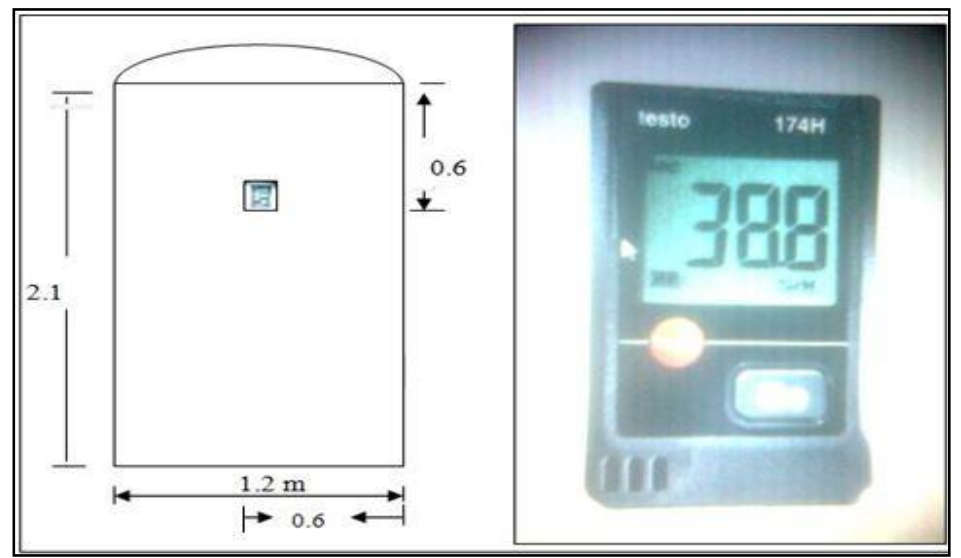

Fig. (1): Instrument (on the right) of measuring air temperature and relative humidity, position it in the middle jumbo (on the left)



Fig (2): Dacom weather station for measuring of solar intensity Number of sprout per tuber. 
This parameter was measured as an average number for each sample 100 tubers for each replicate. This number was used in differentiation between treatments.

\section{RESULTS AND DISCUSSIONS}

\section{Air temperature inside and outside greenhouse}

The average daily air temperature inside greenhouse was $18.79,19.5$ and $19.48{ }^{\circ} \mathrm{C}$. The increasing percent were $(80 \%, 79.6 \%$ and $82.6 \%)$ for storage period 4, 6 and 8days respectively, comparing with the average air temperature outside greenhouse which were $10.29,10.86$ and 10.82 ${ }^{\circ} \mathrm{C}$ for 4,6 and 8 days respectively as showed in figures (3 and 4)

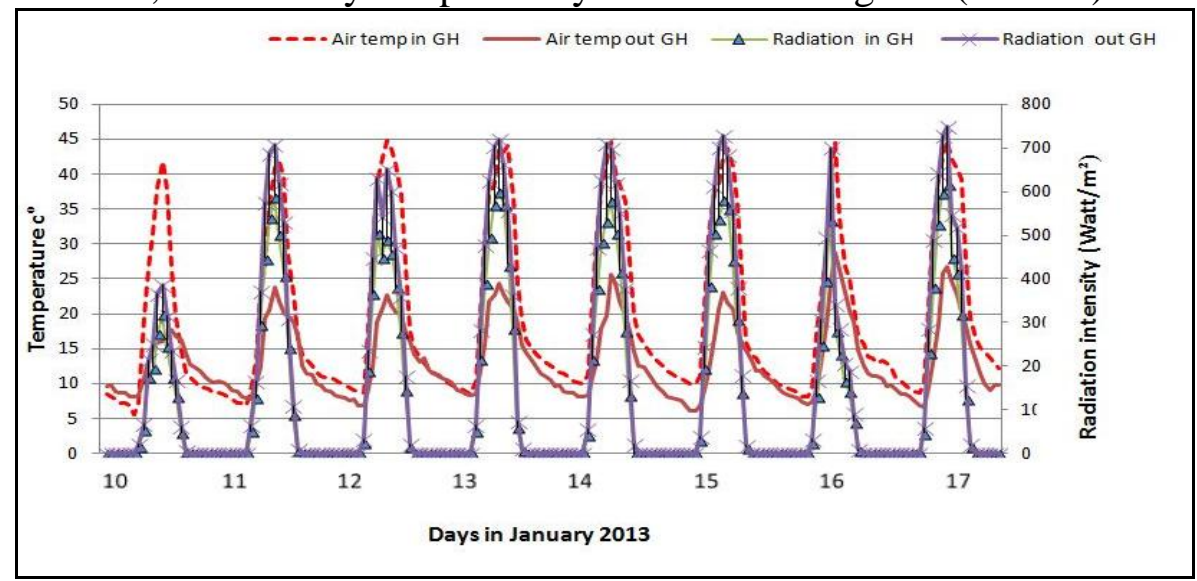

Fig (3):- Air temperature and solar radiation intensity inside and outside the greenhouse for all storage period in January 2013.



Fig (4):-Air temperature and solar radiation inside and outside the greenhouse at 15-January 2013. 


\section{Relative humidity inside and outside the greenhouse}

It reached the average relative humidity inside greenhouse $(77.1 \%, 76.2 \%$ and $76.5 \%)$ decreasing $(12.5 \%, 12.8 \%$ and $12.2 \%)$ compare with average relative humidity outside greenhouse during all the experimental periods $\left(88.1 \%, 87.4 \%\right.$ and $\left.87.1 \%{ }^{\circ}\right)$ for 8,6 and 4 days respectively as presented in figure (5).

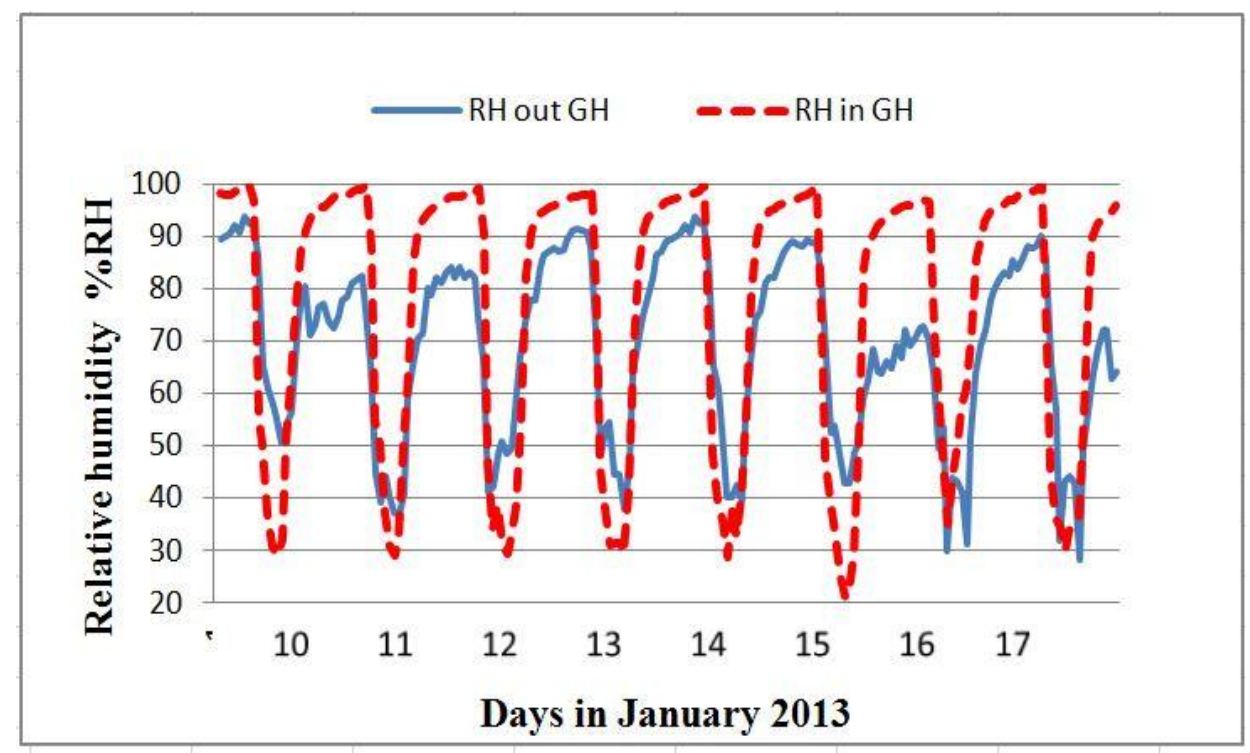

Fig (5):- Relative humidity inside and outside the greenhouse in January 2013.

Air temperature (inside packs of potato seeds) inside and outside greenhouse

Measurements of air temperature for tubers (inside packs of potato seeds) inside and outside the greenhouse was accorded every one hour per day during storage of potato seeds are presented in figures (6 and 7) which describe the air temperature between tubers inside and outside greenhouse fluctuated with the daily amplitude becoming larger at noon .it reached the peak at noon and declined in late afternoon and early morning .The air temperature inside the closed greenhouse reached maximal value which was $20.8{ }^{\circ} \mathrm{C}$ compare with the air temperature 
outside greenhouse that was $16.3{ }^{\circ} \mathrm{C}$ in 13th of January 2013.The minimum value inside and outside greenhouse 14.0 and $11.1{ }^{\circ} \mathrm{C}$ respectively in $11^{\text {th }}$ of January 2013. The average air temperature per day inside greenhouse was $17.25,16.9$ and $16.7{ }^{\circ} \mathrm{C}$ Increasing $(26.7 \%, 22.8 \%$ and $25.9 \%$ )for storage period 8,6 and 4days respectively comparing with average temperature between tubers (inside packs of potato seeds) out greenhouse were $13.62,13.67$ and $13.27 \mathrm{C}^{\mathrm{o}}$.

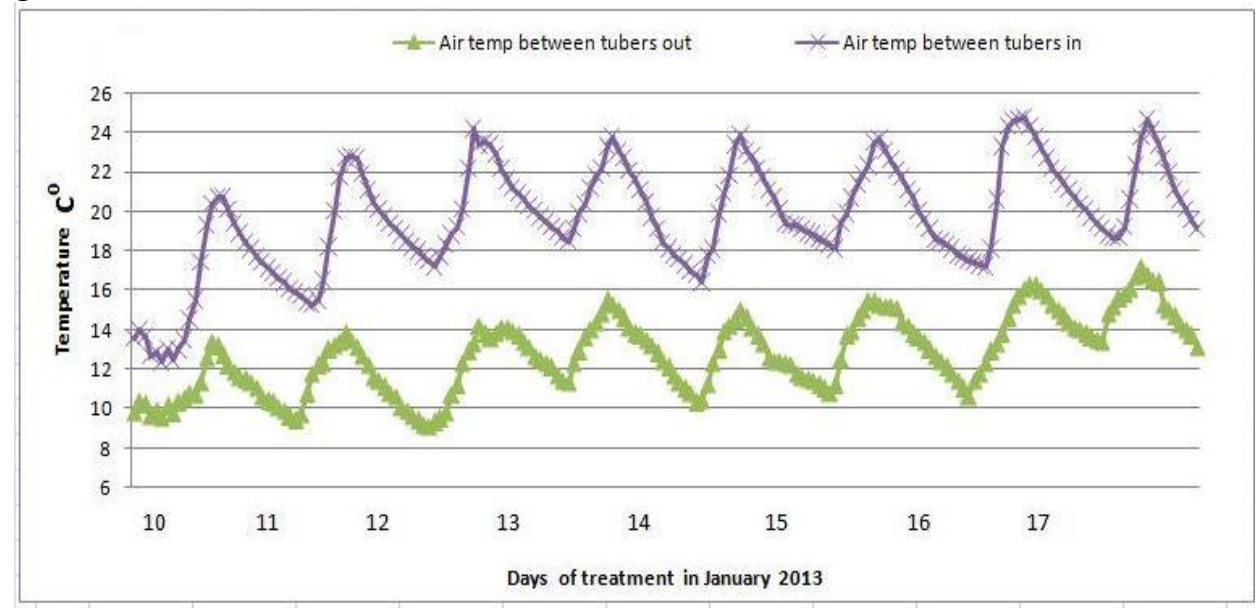

Fig (6):- Air temperature between tubers inside and outside the greenhouse in January 2013.

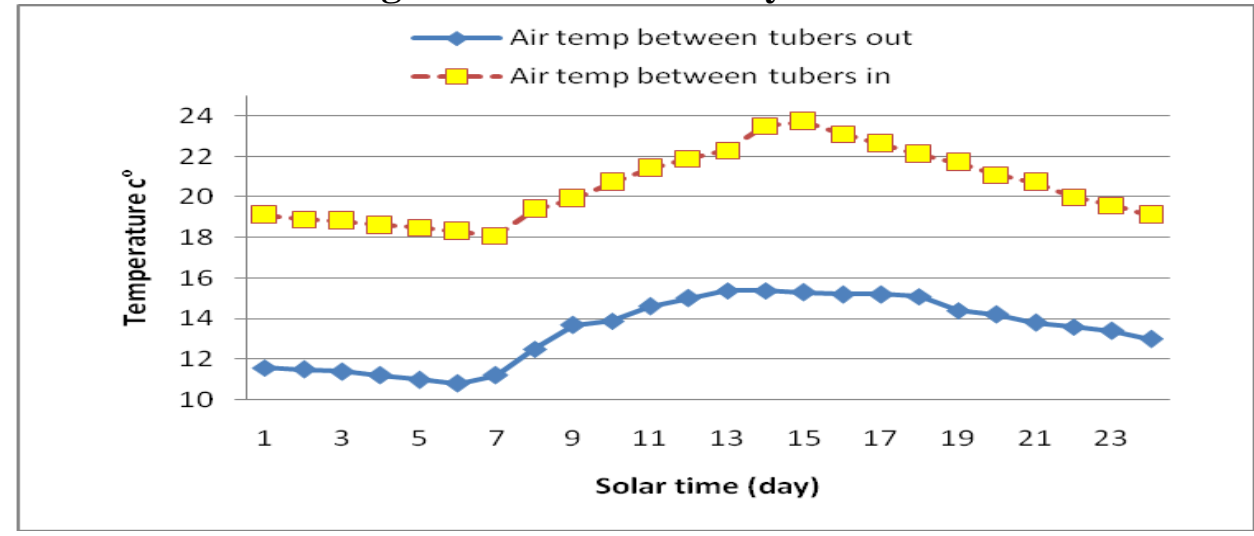

Fig (7):- Air temperature between tubers inside and outside the greenhouse in 15 January 2013.

\section{Radiation intensity}

solar radiation outside and inside the greenhouse reached the maximal value of $672.2 \mathrm{watt} / \mathrm{m}^{2}$ outside the greenhouse, and 529.7 inside the 
greenhouse watt $/ \mathrm{m}^{2}$ respectively, while the maximal value of air temperature inside and outside the greenhouse reached to the maximal value $44.8{ }^{\circ} \mathrm{C}, 20.9{ }^{\circ} \mathrm{C}$ respectively. Relative humidity inside and outside the greenhouse reached to the maximal value $99.9 \%, 99.3 \%$ respectively, while relative humidity of tubers inside the greenhouse reached the maximum value $99.9 \%$ outside the greenhouse reached 90.2\%).The average solar radiation intensity per day outside and inside the greenhouse was $320.34 \mathrm{watt} / \mathrm{m}^{2}$ and $260.9 \mathrm{watt} / \mathrm{m}^{2}$ respectively. It can be observed that, the average difference between outside and inside values of relative humidity was approximatley $22.7 \%$ as presented in figure (8).

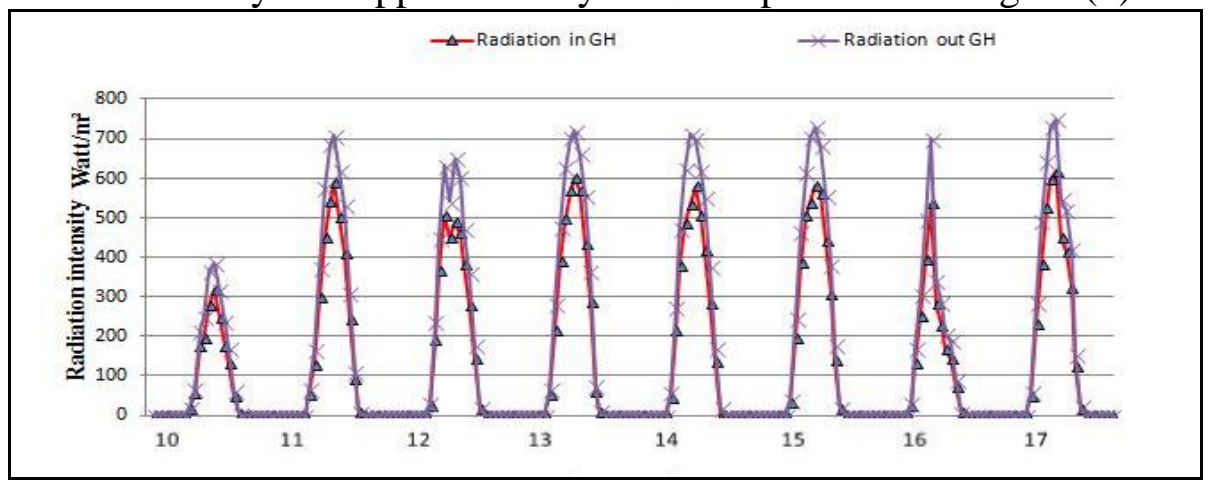

Fig (8):-Solar radiation inside and outside greenhouse for all storage period in January 2013.

\section{Effect of storage in greenhouse on number of sprouts per tuber}

Average number of sprouts per tuber on Innovator verity and their interaction between storage period (inside, outside greenhouse), two sizes and 3 types of pack materials were presented in tables (1 and 2) and figure (9). Sprouts per tuber in size $45-50 \mathrm{~mm}$ and size $35-45 \mathrm{~mm}$, in difference pack materials (Jumbo bags, small bags and wood boxes) inside the closed greenhouse reached the maximal values $(5.8,6.5$ and 5.6) and (4.5, 4.8 and 4.4) sprouts per tuber respectively comparing with the maximum values outside greenhouse which were (3.7, 4.1 and 3.45) and $(3.1,3.55$ and 2.8$)$ sprouts per tuber respectively for period storage 8 days. Sprouts per tuber in Innovator variety size $45-50$ and $35-45 \mathrm{~mm}$ in difference pack materials (Jumbo, Bags and Box) inside the closed greenhouse reached the lowest number (3.1, 3.3 and 2.9) and (2.35, 2.6 and 2.1) sprouts per tuber respectively comparing with value outside 
greenhouse (2.1, 2.2 and 1.5) and (1.1, 1.35 and 0.84) sprouts per tuber respectively for period storage 8 days. The average value for Innovator variety size $45-50 \mathrm{~mm}$ and $35-45 \mathrm{~mm}$ in difference pack materials (Jumbo, Bags and Box) inside greenhouse (4.07, 4.6 and 3.5) and (3.05, 3.4 and 2.43), increasing sprouting according at storage period for 8 days inside and outside greenhouse $(59.6 \%, 65 \%$ and $52 \%)$ in size $45-50$ $\mathrm{mm},(45.2 \%, 47.8 \%$ and $42.9 \%)$ in size $35-45 \mathrm{~mm}$. In case of outside the greenhouse the number was $(2.55,2.78$ and 2.3$)$ for sprouts per tuber in size $45-50 \mathrm{~mm}$, and was $(2.1,2.3$ and 1.7$)$ in size $35-45 \mathrm{~mm}$. The average value for Innovator variety size $45-50$ and $35-45 \mathrm{~mm}$ in difference pack materials (Jumbo, Bags and Box) inside the greenhouse was (3.05, 3.3 and 2.75) and (2.35, 2.87 and 2.13). The increasing percentage was $(37.4 \%, 35.25 \%$ and $44.7 \%)$ in size $45-50 \mathrm{~mm}$ and (23.6\%, 36.6 and $25.3 \%)$ in size $35-45 \mathrm{~mm}$ for 6 days storage, compared with average value outside greenhouse $(2.22,2.44$ and 1.9) and (1.9, 2.1 and 1.7) sprouts per tuber respectively. It reached to its average value for 45-50 and 35-45 mm in difference pack materials Jumbo, Bags and Box inside greenhouse $(2.76,2.95$ and 2.4) and (1.97, 2.2 and 1.91) increasing $(36 \%, 40.4 \%$ and $28.3 \%)$ in size $45-50$ and $(24.6 \%, 25.7 \%$ and $27.3 \%)$ in size $35-45$, for 4 days storage, compared with average value outside greenhouse (2.03, 2.1 and 1.87) and (1.58, 1.75 and 1.5) sprouts per tuber respectively.

In general a storage period of 8 days inside the greenhouse for all pack materials in Innovator variety size $45-50$ and $35-45 \mathrm{~mm}$ achieved the higher sprouts per tuber seeds than all treatments inside and outside the greenhouse followed by 6 days storage inside the greenhouse and 4days inside the greenhouse, and 8 days outside greenhouse respectively comparing with least rate of sprouts per tubers outside the greenhouse for 4 and 6 days in all pack materials.

\section{Effected of packing materials on numbers of sprouts per tuber.}

Storage inside the greenhouse appears no difference between small bags and jumbo bags but for both pack materials the difference was consider able more than woody boxes inside treatments 8 and 6 days for seed size $45-50 \mathrm{~mm}$, comparing with storage period 4 days. No difference in back 
materials between jumbo bags and woody boxes and also between jumbo and small bags but small bags achieve more number of sprouts per tuber than woody boxes. In size $35-45 \mathrm{~mm}$, with 8 days storage there was no difference between pack materials jumbo and small bags pack but woody boxes was with less number of sprouts. With 4 and 6 days storage there was no difference between jumbo and woody boxes but with small bags larger numbers of sprouts was obtained more than woody boxes.

Tuber seed size $45-50 \mathrm{~mm}$ achieved more number of sprouts per tuber than tuber seed sizes $35-45 \mathrm{~mm}$ in case of storage inside and outside the greenhouse for all storage period 8, 6 and 4 days, except for 4 and 6 days storage outside the greenhouse.

Less significant difference between treatments was occurred where it was 0.4 in size $45-50 \mathrm{~mm}$ and 0.45 in size $35-45 \mathrm{~mm}$.

Table (1):- Effect of different storage period and different pack materials on number of sprouts per tuber, size $45-50 \mathrm{~mm}$

\begin{tabular}{|c|c|c|c|c|c|c|}
\hline \multirow{2}{*}{$\begin{array}{c}\text { Types } \\
\text { of pack }\end{array}$} & \multicolumn{5}{|c|}{ Number of sprouts / tuber seeds size 45-50 mm } \\
\cline { 2 - 4 } & 4 days & 6 days & 8 days & 4 days & 6 days & 8 days \\
\cline { 2 - 4 } & & & & & & \\
\hline \multirow{2}{*}{ Jumbo } & 2.03 & 2.22 & 2.55 & 2.76 & 3.05 & 4.07 \\
Bags & 2.1 & 2.44 & 2.78 & 2.95 & 3.3 & 4.6 \\
Box & 1.87 & 1.9 & 2.3 & 2.4 & 2.75 & 3.5 \\
\hline L. S. D = & \multicolumn{7}{|c|}{0.4} \\
\hline
\end{tabular}

* Values represents the average of 4 replicates, each replicate contain 100 tubers.

Table (2):-Effect of different storage period and different packs materials on numbers of sprouts per tuber, Innovator variety size 35-45 mm.

\begin{tabular}{|l|c|c|c|c|c|c|}
\hline \multirow{3}{*}{$\begin{array}{c}\text { Types } \\
\text { of pack }\end{array}$} & \multicolumn{5}{|c|}{ Number of sprouts / tuber seeds size 35-45 mm } \\
\cline { 2 - 7 } & 4 days & 6 days & 8 days & 4 days & 6 days & 8 days \\
\hline & & & & & & \\
Jumbo & 1.58 & 1.9 & 2.1 & 1.97 & 2.35 & 3.05 \\
Bags & 1.75 & 2.1 & 2.3 & 2.2 & 2.87 & 3.4 \\
Box & 1.5 & 1.7 & 1.7 & 1.91 & 2.13 & 2.43 \\
\hline L. S. D = & \multicolumn{6}{|c|}{0.4} \\
\hline
\end{tabular}

* Values represents the average of 4 replicates, each replicate contain 100 tubers. 

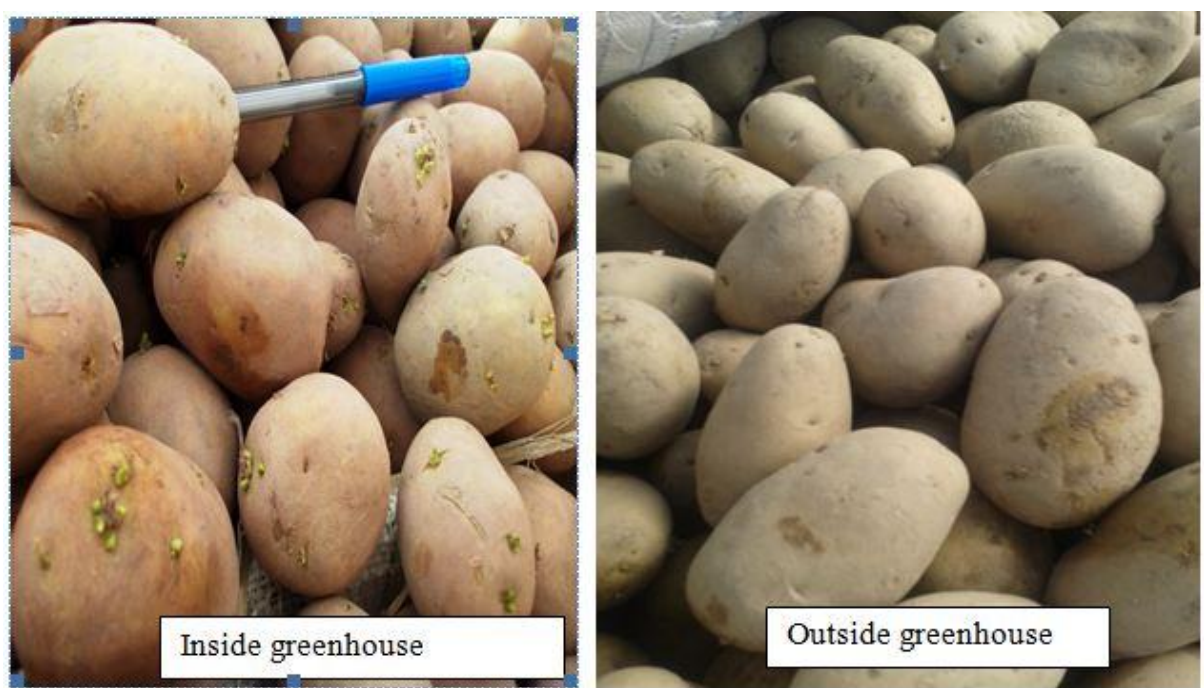

Fig. (9):-Number of sprouts per tuber, in Innovator variety size 45$50 \mathrm{~mm}$ inside and outside greenhouse before planting.

\section{4- CONCLUSION}

1. Using of solar energy as renewable energy technologies, important would be for green houses as a source of heat for used it in storage seed potato seeds before planting to increase potato tubers seeds sprouting for production improvement.

2. - The best storage period to do good sprouting before planting in imported potato seeds (Innovator variety) 8 days storage inside closed greenhouse covered by plastic material, to planted it in spring season to get on earlier emergence, more stems per square meter, more numbers of new tuber yield and more yield.

3. -Storage potato seeds inside closed greenhouse before planting are better in the yield than storage of potato seeds outside greenhouse under the same period of storage, the same package materials and the same size to each treated.

4. Storage of potato seeds inside pack materials jumbo bags and small bags are better than woody boxes to get more sprouts. 
5. The average daily air temperature inside greenhouse was $18.79,19.5$ and $19.48{ }^{\circ} \mathrm{C}$, for storage period 4,6 and 8days respectively may be resulted to effected on Cytokinins, Gibberellins and Auxins inside seed tubers are involved in dormancy break, sprouting early and less growth inhibitor activity comparing with the average air temperature outside greenhouse which were $10.29,10.86$ and $10.82{ }^{\circ} \mathrm{C}$ for 4,6 and 8 days respectively were less sprouting.

\section{REFERENCES}

Allen,R.G.;Pererira,L.S.;Raes,D.and Smith,M.(1998):'FAO irrigation and Drainage. CropEvapo transpiration Pp. No.56.

Beukema, H. and D.E. van der Zag, (1990) :"Introduction to potato production".pudoc, Wageningen, Netherlands .pp.208.

Bryan, J.E.(1989)"Breaking dormancy of potato tubers "Research Guide 16.CIP(center international potatoes)

Boulard,T.; H. Fatnassi ; J.C. Roy ; J. Lagier ; J. Fargues; N. Smits; M. Rougier andB. Jeannequin (2005) : "Effect of greenhouse ventilation on humidity of inside air and in leaf boundary-layer" Elsevier Ltd. 125 (3-4), PP. 225-239. http://dx.doi.org /10.1016/j.agrformet.2004.04.005.

Delaplace, P., Rojas-Beltran, J., Frettinger, P., du Jardin, P. and Fauconnier, M.L. (2008) : " Oxylipin profile and antioxidant status of potato tubers during extended storage at room temperature". Plant Physiology and Biochemistry 46: 1077- 1084.

Duffie,J. A. and W,A.Beckman(1980):"Solar engineering of thermal processes "Wiley- Interscine Newyork.

Pande, P.C., Singh, S.V., Pandey, S.K. and Singh, B.( 2007): "Dormancy, sprouting behavior and weight loss in Indian potato (Solanumtuberosum) varieties". Indian Journal of Agricultural Sciences 77 (1): 715-720. 
Roberts, W.J.(1997) :" Environmental control of green houses" Rutgers University , Cook College. CCEA, Center for Controlled Environment Agriculture, pp 1 - 19. http://aesop.rutgers.edu/ horteng /Fact Sheets / EnvControlofGHs.pdf

Wang, F.X.; S.Y. Feng ;X.Y. Hou ;S.Z. Kang and J.J.Han (2009):"Potato growth with and without plastic mulch in two typical regions of Northern China" Field Crops Research.110(2).pp.123-129.

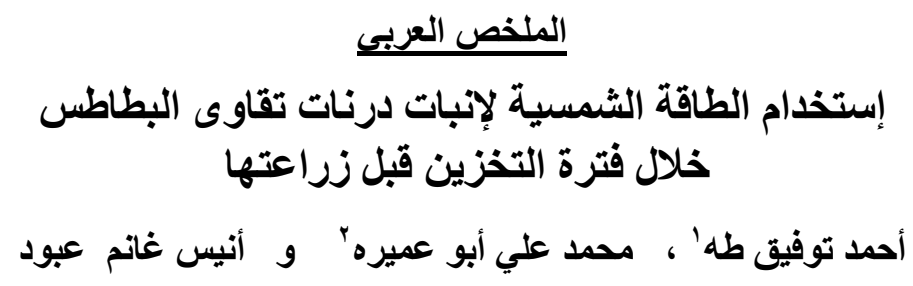

أجريت هذه الدراسه بمزرعة الثركه العالميه للتنميه الزراعيه(فارم فرينس مصر) بوادي





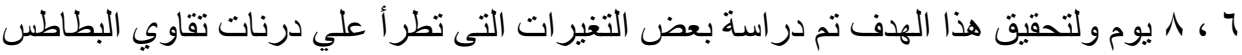

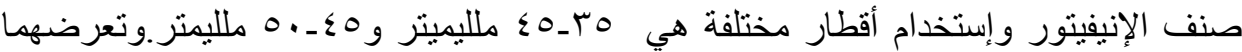

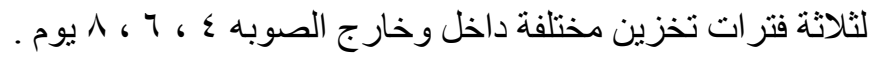
توصلت الدراسه إلي النتائج الأتيه:

1 ـ ـ متوسط درجة الحر ارة داخل الصوبة للثلاثة فترا ت التخزين المختلفة ؛ ، 7 ، ، 1 يوم كانت أعلي

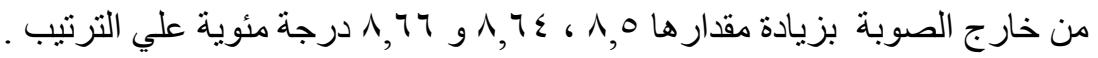

r- متوسط درجة الحرارة بين درنات التقاوي المخزنه داخل الصوبة للثلاثة فترا ت التخاء التخزين

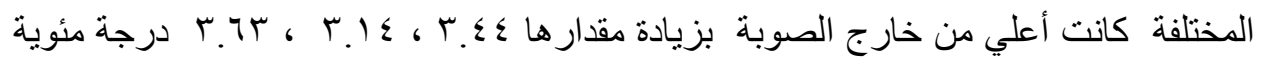





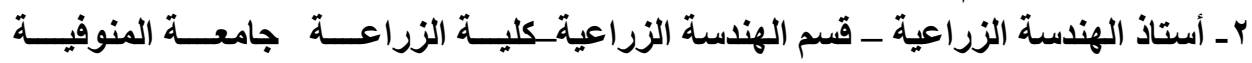
r- مدير الزراعهـ الثركه العالمية للتنميه الزراعيه (فارم فريتس-مصر) 


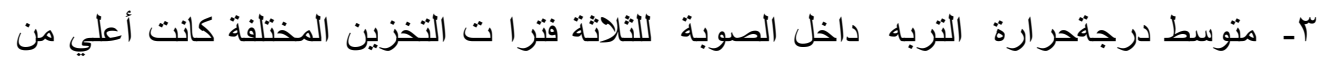





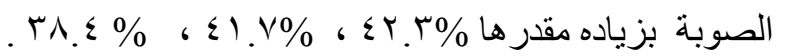

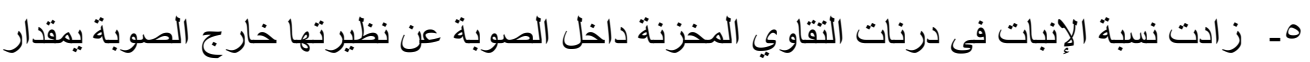

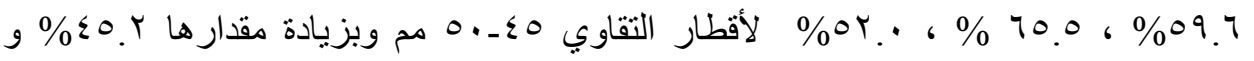

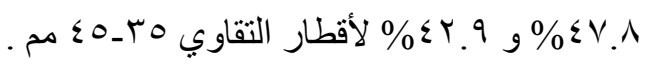

